\title{
Shear strength and root length density analyses of Entisols treated with palm oil mill effluent sludge
}

\author{
Mohd Nizar Khairuddin ${ }^{1,2 *}$, Isharudin Md Isa ${ }^{1}$, Abd Jamil Zakaria ${ }^{2}$, Hamdan Jol', and Syahrizan Syahlan ${ }^{3}$ \\ ${ }^{1}$ Department of Land Management, Faculty of Agriculture, Universiti Putra Malaysia, \\ 43400 UPM Serdang, Selangor, Malaysia. \\ ${ }^{2}$ Institute of Agricultural Production and Food Innovation (AGROPOLIS), \\ Universiti Sultan Zainal Abidin, Campus Tembila, 22200 Besut, Terengganu, Malaysia. \\ ${ }^{3}$ Faculty of Plantation and Agrotechnology, Universiti Teknologi MARA Melaka, Campus Jasin77300 Merlimau, \\ Melaka, Malaysia.
}

\begin{abstract}
The underutilized and improper management of wastewater such as palm oil mill effluent sludge (POME) sludge might create pollution and give a negative impact towards the environment. This study was aimed to evaluate the effect of shear strength parameter and root length density of maize on Entisols applied with POME sludge as a soil amendment. The maize was planted on Rasau soil series (Entisols) amended with different POME sludge treatment systems from various ponds (mixing, anaerobic, facultative, algae, and dumping). Standard direct shear box test was used to identify the cohesion (c) and angle of internal friction ( $\phi)$ after application of treatments. The bulk density, porosity, moisture content, organic matter, root length and root density of Zea mays L. (Hibrimas) applied with POME sludge from dumping pond (DP), aglae pond (ALP) and facultative pond $(F P)$ were significantly difference against the control treatment. The positive effect of root length and root length density (RLD) treated with POME sludge from the dumping pond was $26 \%$ and $38 \%$ compared to the other treatments. The results highlighted that roots enhanced soil shear strength by reducing the cohesion and increased the angle of internal friction component. The shear strength analysis showed that high shear strength of normal stress at $500.72 \mathrm{kN} / \mathrm{m}^{2}$ was measured from the dumping pond's POME sludge treatment after maize harvesting. The POME sludge from the DP, $A L P$ and FP was ameliorating some nutrients deficiencies for the plant growth and improved the root length density. In conclusion, the POME sludge from the DP indicated the high shear strength and root length densitie due to the adequate nutrients for roots distribution and maize growth.
\end{abstract}

Keywords: Shear strength, root length density, Entisols, POME sludge

\section{Introduction}

Maintaining and replenishing organic matter into the soil is important to sustain the productivity of the soil in the tropical climate. Generally, Malaysia had produced about half of organic waste from oil palm industry, which has not been fully utilized. According to Embrandiri et al., (2013) palm oil mill effluent (POME), palm kernel cake, decanter cake, empty fruit bunch and palm kernel shell were potential to be processed and used as an organic matter amendment for land application. Recently, some studies were using decanter cake with lady's finger (Embrandiri et al., 2013), tannery sludge with capsicum plants (Silva et al., 2010), cowpea (Silva et al., 2013) and olive mill waste with lettuce and chicory (Kelepesi and Tzortzakis, 2009) as their organic matter materials for soil amendment. Unfortunately, only a few studies were focused on POME sludge as a soil amendment for the plant growth. According to Khairuddin et al., (2016), the treated POME sludge was identified equally balance with $\mathrm{C}, \mathrm{N}$, and macronutrients $(\mathrm{P}, \mathrm{K}, \mathrm{Ca}$,
$\mathrm{Mg}, \mathrm{S}, \mathrm{Na}$ ). Mostly, these elements were vital for soil improvement and productivity of the crops. Moreover, heavy metal content in POME sludge was in accordance with the standard from WHO/FAO that is safe for human consumption.

The influence of soil physical condition on plant growth associated with agricultural practices has been emphasized and preferably more on the roots against the stability of the soil. Climate also played an important role in influencing the physiological aspect of plant establishment such as roots (Terzaghi and Peck, 1967). The roots reinforced the soil through the mechanical and hydrological mechanism and also stabilized the soil water content from exceeding the field capacity (FC) (Normaniza and Barakbah, 2006). Root absorbs and circulates water to the atmosphere rather than percolating deep into the soil profile. Plant roots play an important role in resisting the shallow landslip and topsoil erosion of slopes by raising soil shear strength. The method to determine the soil

\footnotetext{
*Email: imi@upm.edu.my
} 
strength was obtained using the direct shear test analysis. Shear strength of a soil mass is the internal resistance per unit area that the soil mass can offer to resist failure and slide along any plane inside it. The presence of roots would result in an overall increase of the soil strength. This arises from the combined effects of soil reinforcement by a mass of roots (Mohamad Nordin et al., 2011) and soil moisture depletion by evapotranspiration (Ali and Osman, 2008). Other factors, which affect the soil strength was soil moisture content, particle size distribution (soil texture), and the mineralogical content of the different soil series.

The shear strength of the soil was a measure of its cohesiveness and resistance to shearing forces exerted by gravity, moving fluids and mechanical loads. Its strength was derived from the frictional resistance met by soil constituent particles when they were forced to slide over one another or to move out of interlocking positions, the extent to which stresses or forces were absorbed by solidto-solid contact among the particles, cohesive forces related to chemical bonding of clay minerals, and surface tension forces within the moisture films in unsaturated soils. The objectives of this study were to determine the effect of root length density and shear strength of Entisols amended with palm oil mill effluent (POME) sludge.

\section{Materials and Methods}

\section{Study site}

The field experiment is located at Research Farm in the Universiti Teknologi MARA Pahang, Jengka Campus, Pahang, Malaysia $\left(3.7562{ }^{\circ} \mathrm{N}, 102.5611^{\circ} \mathrm{E}\right)$ for a period of Feb 2015 until June 2016. It was a tropical climate with the average temperature of $31^{\circ} \mathrm{C}$, rainfall at $2300 \mathrm{~mm}$ per annum and relative humidity was $60-80 \%$. The POME sludge samples were taken from palm oil mill, Felda Jengka 8, Bandar Tun Abdul Razak Jengka, Pahang, Malaysia from the treatment ponds system; mixing (MP), anaerobic (ANP), facultative (FP), algae (ALP), and dumping pond (DP)). POME treatment system was differentiated based on the Hydraulic Retention Time (HRT): cooling ponds (1 day), mixing ponds (2 days), anaerobic ponds (45 days), facultative ponds (20 days), algae ponds (7 days) and dumping pond (more than 6 months) after discharged from palm oil mill. The hydraulic retention time (HRT) was also reflected to the decomposition rate and characteristics of the POME sludge. According to Khairuddin et al., (2016), millions of tonnes of POME sludge was discharged into the dumping pond for maintenance purposes. Figure 1 shows the POME sludge samples collected from the treatment ponds. Physically, they were blackish, textured and smelly. The DP sludge (A) was blackish in color and less smelly. Furthermore, less moisture and dark brownish color was shown in ALP sludge (B), ANP sludge (C), and FP sludge (D). Lastly, POME sludge from MP sludge (E) was shown to be oily and of dark yellowish color compared to the other sludge.

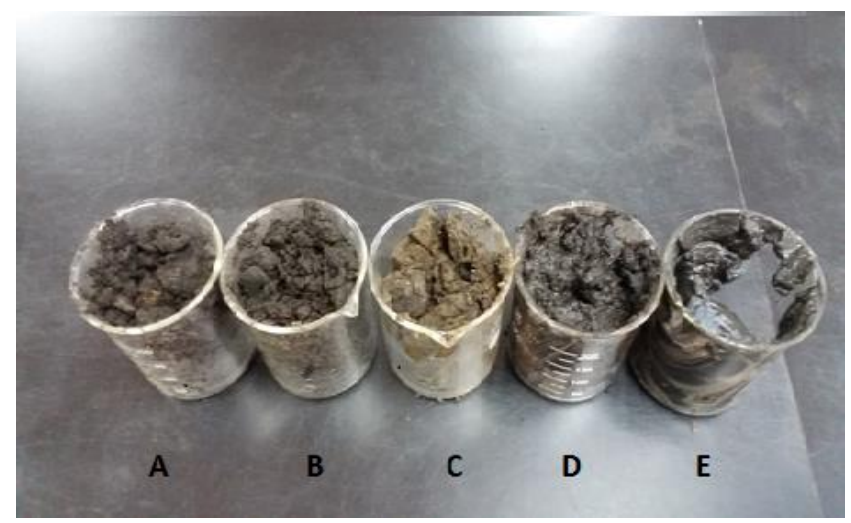

Figure 1: The POME sludge samples from DP (A), ALP (B), FP (C), ANP (D), and MP (E)

\section{Experimental design}

The experiment was set-up in the field using polybags in randomized completely block design (RCBD) with three replications. Maize was planted in the polybags of $16 \mathrm{~cm} \mathrm{X}$ $20 \mathrm{~cm}$. The different POME sludge from mixing, cooling, anaerobic, facultative, algae and dumping ponds were used as soil amendment. $30 \%$ of $\mathrm{w} / \mathrm{w}$ of POME sludge was applied and uniformly mixed with soil for each of the treatment. Rasau soil series (Entisols) was selected due to deficient organic matter content, $\mathrm{pH}, \mathrm{CEC}$ and a characteristic of weakly developed profiles. In this study, $a$ Zea may L. (Hibridmas variety) was planted to investigate the root growth performance. POME sludge was applied once and mixed with Rasau soil for each polybag. Drip irrigation system was used for watering the maize twice a day per plant. The maize was harvested after 75 days of planting (DAP).

\section{Selected soil physicochemical properties}

Soil and POME sludge samples were analyzed for selected soil physiochemical properties (bulk density, soil porosity, moisture content and organic matter). The bulk density (Eqn. 1) was measured using a core method (Blake and Hartge, 1986). Indeed, the sample was also used to determine the field moisture content (Eqn. 2) (Teh and Talib, 2006). Usually, the measurement of bulk density and moisture content allows total porosity (Eqn. 3) (Teh and Talib, 2006) to be measured, respectively. Organic matter in the soil was determined using CNS analyzer (LECO CNS-2000) (Kowalenko, 2001) as under: Bulk density $\mathrm{p}_{\mathrm{b}}(\mathrm{g}$ $\mathrm{cm}^{-3}$ ) was measured 
$\mathrm{Pb}=\frac{W b-W r}{\frac{\pi h d^{2}}{4}}$

Where $W_{b}$ is the soil and core after oven-drying $(\mathrm{g}) ; W_{r}$ is the weight of the core ring $(\mathrm{g}) ; h$ is the core ring height or depth $(\mathrm{cm})$; and $d$ is the core ring diameter $(\mathrm{cm})$

Soil water content qw, expressed on a dry mass basis;

$\theta w=\frac{W a-W b}{W b-W r}$

where $\mathrm{W}_{\mathrm{a}}$ is the weight of the soil and core ring before oven-drying (g)

Soil porosity e;

$\mathrm{e}=1-\frac{p b}{p_{p}}$

where $\mathrm{p}_{\mathrm{p}}$ is the particle density $\left(\mathrm{g} \mathrm{cm}^{-3}\right)$. For most mineral soils, particle density is $2.65 \mathrm{~g} \mathrm{~cm}^{-3}$

\section{Shear strength analysis}

Soil shear strength or shear stress at failure was determined by the direct shear box test (Head, 1982). Briefly, 25-cm think intact soil samples $(20 \mathrm{~cm} \mathrm{x} 20 \mathrm{~cm} \mathrm{x}$ $100 \mathrm{~cm}$ ) were cut at $25-\mathrm{cm}$ intervals in each wooden box and the edges carefully trimmed. The sample was packed in a metal shear box following the procedure described by (Head, 1982). The sample was then placed in the shear box. Half of the shear box was carefully separated using spacing screws to set a gap slightly larger than the largest soil grains present. Clamping the loading head in place using the setscrews was done for that purpose and then the separation screws were taken out. The normal load needs to reflect the applied vertical load plus the weight of the load block and top half of shear box. Shear deformation dial gauge was attached and both vertical and horizontal gauges were set to zero. The angle of internal friction was determined by placing the soil in a rigid metal box, square in plan, consisting of two horizontal halves. During the shearing process, the relative displacement of the two portions of the specimen and the applied shearing force were both measured so that a load/displacement curve could be plotted. The vertical movement of the top surface of the specimen, which indicates changes in volume, was also measured and enabled changes in density and void ratio to be determined during shear. This shear box test was the standard quick test carried out in a $60 \mathrm{~mm}$ square shear box, which has been the most common size used in the UK and the USA (Head, 1982).

Horizontal (shear) loading was then started and readings of horizontal load shear displacement, and vertical (volume-change) displacements were taken. The speed of
$0.025 \mathrm{~mm} / \mathrm{min}$ was used at regular intervals (every 30 seconds), readings of the load dial, the vertical movement dial and the time were recorded. Normal stress of $100 \mathrm{kN}$ $\mathrm{m}^{-2}, 200 \mathrm{kN} \mathrm{m}^{-2}$ and $300 \mathrm{kN} \mathrm{m}^{-2}$ were used for every layer of the soil profile samples. Shearing was continued until the maximum stress or peak point has been clearly defined, that is until at least four consecutive readings indicate a decrease or equal to load. If a peak was not observed, shearing should continue until the full length of travel of the box had been reached. A set of three specimens was usual but additional specimens were tested when required. A plot of the Mohr-Coulomb failure envelope is used to determine the shear parameters; cohesion $(c)$ and internal angle of friction $(\phi)$ as outlined in Section 3 (Head, 1982). Given the linear relationship between shear strength, and $c$ and $\phi$, evaluation of roots of shear properties was limited to shear strength. The coulomb envelope was the relationship between maximum shear stress related to normal stress from shear box tests (Tan, 2003). In soil, for practical purposes, this linear relationship holds good and it represents the most widely accepted criterion of failure. The shear stress at failure, $\tau f$, against the corresponding normal stress, $\sigma \mathrm{n}$, for each specimen was plotted. This line is the failure envelope or the Coulomb envelope. The angle of inclination $\phi$ of the failure envelope to the horizontal axis was measured to the nearest $1 / 20$. The cohesion intercept $c$ $\left(\mathrm{kN} \mathrm{m}^{-2}\right)$ on the vertical axis was identified after the graph has been plotted (Head, 1982).

Shear strength is a key determinant of slope stability and soil detachment during erosion processes. Therefore, the current study used the Mohr-Coulomb failure criterion as a framework for evaluating the effect of nutrient and lime application on root-induced shear strength properties. According to the limit equilibrium theory, the safety factor $\left(F_{s}\right)$ is used to evaluate slope stability and soil susceptibility to detachment. Fs is the ratio of stresses resisting failure to the stresses required to bring the slope into a state of limiting equilibrium along a given failure surface (Eqn. 4) (Ali and Osman, 2008).

$F_{s}=\frac{s}{\tau}$

where $s$ is the shear strength of the soil and $\tau$ is shear stress acting along the failure surface. According to the MohrCoulomb $(1776,1900)$ failure criterion, the total shear strength or shear stress of earth material at failure consists of cohesion and friction components (Eqn. 5) (Morgan, 1996):

$s=c+\sigma_{n} \tan \phi$

where $s$ is a shear strength or shear stress at failure $\left(\mathrm{kN} \mathrm{m}^{-}\right.$ $\left.{ }^{2}\right), c$ is cohesion $\left(\mathrm{kN} \mathrm{m}^{-2}\right), \sigma_{\mathrm{n}}$ is the total stress normal to the 
shear plane $\left(\mathrm{kN} \mathrm{m}^{-2}\right)$, and $\phi$ and $\tan \phi$ are the angle and coefficient of internal friction of the material, respectively. Roots permeated earth materials behave like composite materials, in which elastic roots of high tensile strength are embedded in a relatively elastic soil matrix. Overall, roots contribute additional apparent cohesion $\left({ }^{C_{r}}\right)$, but have negligible influence on the frictional component of soil shear strength. Slope failures are associated with saturated conditions and excessive build-up of pore-water pressure (Abernethy and Rutherfurd, 2000). When pore water pressure is significant, the total normal stress $\left(\sigma_{n}\right)$ is replaced by effective stress $\left(\sigma_{n}-\mu\right.$ ) [11]. Accounting for the effects of both roots and pore-water pressure on shear strength $(s)$ yields (Eqn. 6) (Ali and Osman, 2008).:

$s=c^{\prime}+c_{r}+\left(\sigma_{n}-\mu\right) \tan \phi^{\prime}$

where, $c^{\prime}$ and $\phi^{\prime}$ denotes effective stress parameters

\section{Root length density}

Root data were collected from a field site. After that, the root was separated from the soil by vigorously rinsing at low pressure with water out of the polybags. The roots were extracted, cleaned and spreading it on a plate. The roots were scanned for root length density using root scanner analysis (WinRhizo Pro, Régent Instruments, Québec, Canada) (Shang et al., 2016). Root length density (RLD) was calculated in each core as the total root length divided by the volume of each core (calculated as a cylinder). A total of root length, the volume of the root, and an average diameter of the roots are important characteristics to be considered when describing and comparing the roots system.

\section{Statistical analysis}

A statistical analysis was conducted using SAS 9.4 statistical package (SAS, 2007). Analysis of variance (ANOVA) was done to test the treatments effect while means separation was used using LSD test at $\mathrm{P} \leq 0.05$.

\section{Results and Discussion}

\section{Selected soil physicochemical properties}

The soil amended with different POME sludge (mixing, cooling, anaerobic, and facultative, algae and dumping ponds) was analyzed to determine the bulk density, porosity, moisture content and organic matter content. Figure 2 shows a significant difference of POME sludge's bulk density from the different treatment ponds. In general, the highest bulk density for each treatment was control (C) $\left(1.44 \mathrm{~g} \mathrm{~cm}^{-3}\right)$, MP $\left(1.27 \mathrm{~g} \mathrm{~cm}^{-3}\right)$, ANP $(1.26 \mathrm{~g}$ $\left.\mathrm{cm}^{-3}\right)$, FP $\left(1.22 \mathrm{~g} \mathrm{~cm}^{-3}\right)$, and ALP $\left(1.19 \mathrm{~g} \mathrm{~cm}^{-3}\right)$. The lowest bulk density was in DP treatment $\left(1.02 \mathrm{~g} \mathrm{~cm}^{-3}\right)$. The bulk density showed that there was significant difference between control and DP treatments. However, there was no significant difference in ANP, FP, and ALP. This trend may be attributed to the high value of organic matter content in the POME sludge as compared to the control (Figure 2). According to USDA (2008), loose soil, porous, and high organic matter content correlated to low bulk density. Moreover, Khaleel et al., (1981) clarified that the effect of organic matter on bulk density of soil was similar with the finding in this experiment. Soil bulk density is a basic soil property that correlates to soil compaction, which is influenced by soil physical and chemical characteristics such as soil texture, the amount of organic matter in the soil, constituent of minerals, and porosity (Chaudhari et al., 2013).

The soil porosity result was presented in Figure 2. Porosity increased significantly in C (45\%) and DP (61\%), respectively, whereas no significant difference was reported in MP (52\%), ANP (52\%), FP (53\%) and ALP (54\%). Therefore, a POME sludge treatment with low bulk density was correlated to high soil porosity. The increase of soil porosity might reduce the soil compaction and improve the soil structure. According to Pagliai et al., (1993), a soil structure might improve with the increases of soil porosity. Soil porosity is formed due to the penetration and movement of roots and soil organisms. The roots and soil organisms create more pores for soil aeration and water storage in the soil. High bulk density correlated to low volume of porosity which depends on soil texture and structure (Kumari et al., 2014). Water can be held tighter in smaller pores than in large ones, so fine soils can hold more water than the coarse soils (Ball, 2001).

The moisture content characteristics of soil treated with POME sludge are presented in Figure 2. The DP sample was the highest (16.44\%) followed by ALP (14.81\%), FP $(13.40 \%)$ and the lowest was control treatment (11.01\%). However, there was no significant difference between ANP $(13.48 \%)$ and MP (12.68\%). This might indicate that moisture content of the soil was contributed by the organic matter content. Using POME sludge from DP, ALP and FP recorded high organic matter content that may be attributed to the water-holding capacity of the soil. According to Bláhová et al., (2013), water can act as binding agent among the soil and with organic matter, it may influence the structural stability and strength of the soil.

The organic matter of the POME sludge in DP treatment was $2.68 \%$, whereas for ALP, FP, ANP and MP were $2.65,2.32,2.32$ and $2.01 \%$ reduction in each treatment as compared to the control $(1.15 \%)$. Figure 2 
shows that there was significant difference between the DP, MP and the control treatment, respectively. POME sludge increased organic matter content, decreased the bulk density and provided more nutrients to the soil. According to Pascual, et al., (1997), organic amendments showed a greate effect in decreasing the $\mathrm{C}: \mathrm{N}$ ratio. Hao et al., (2008), stated that the application of organic amendments generally elevates the soil organic matter and microbial biomass contents to a much greater extent. Therefore, it was proven in this study that all the POME sludge treatments contain high organic matter compared to the control treatment. Indirectly, it could also assist in producing high yield as well as better growth of the plant.
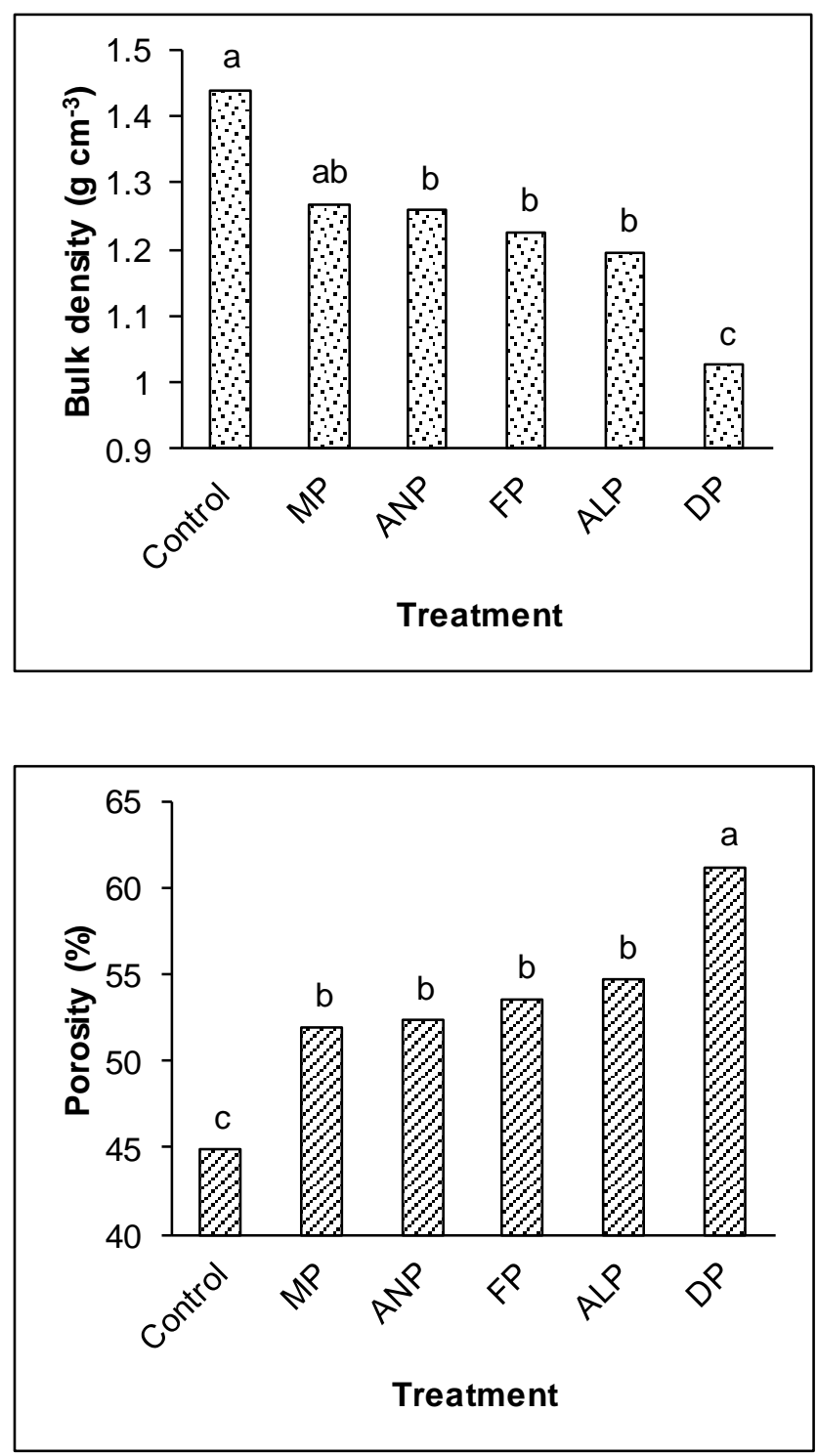
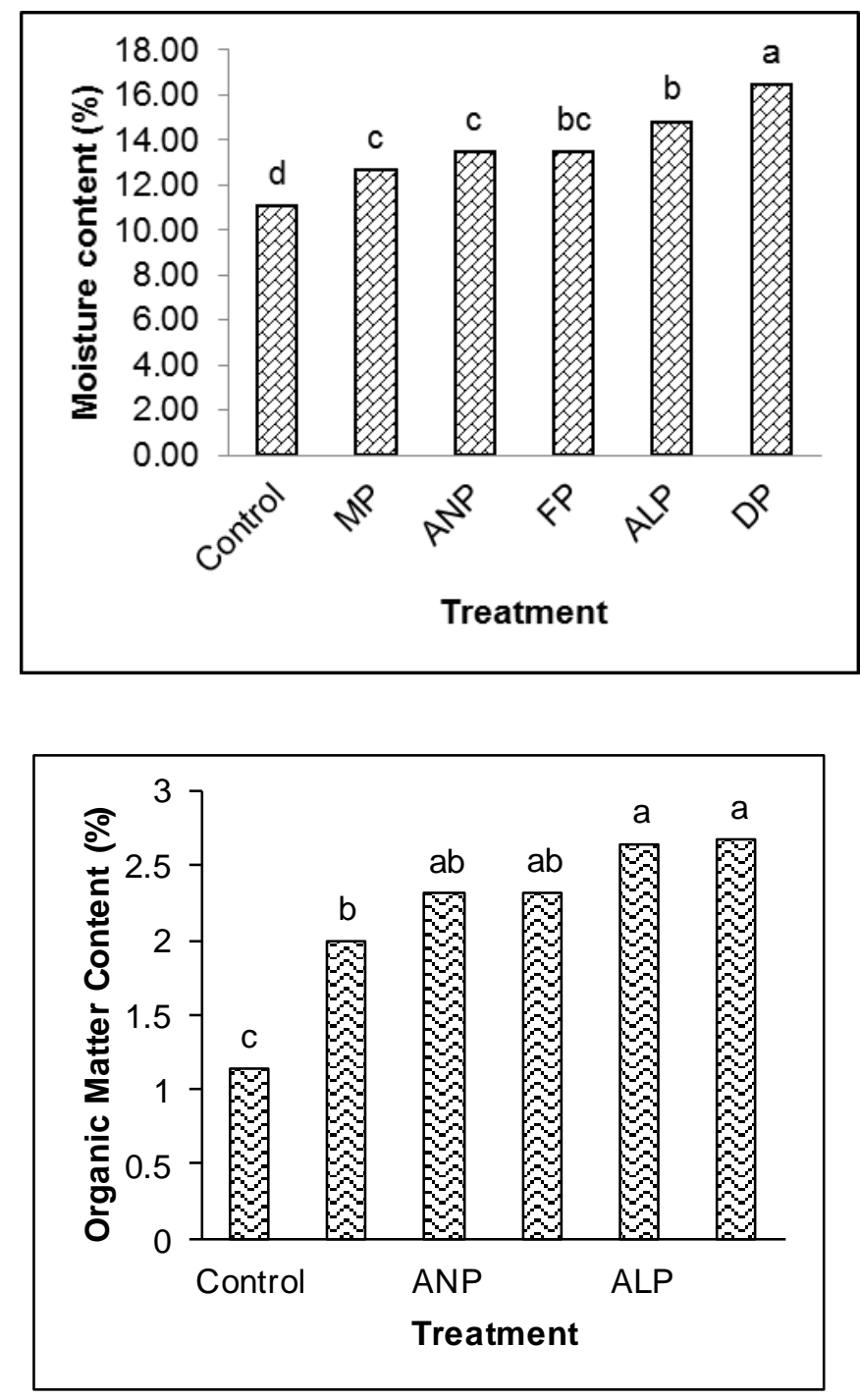

Figure 2: Bulk density, soil porosity, soil moisture and organic matter in different POME sludge treatments (Means with the same letter are not significantly different at $p<0.05$ )

\section{Root length density}

Root length density measurement of DP $(334.16 \mathrm{~cm}$ $\left.\mathrm{cm}^{-3}\right)$ and control $\left(75.53 \mathrm{~cm} \mathrm{~cm}^{-3}\right)$, showed significant difference compared to ALP $\left(271.70 \mathrm{~cm} \mathrm{~cm}^{-3}\right)$, FP $\left(258.24 \mathrm{~cm} \mathrm{~cm}^{-3}\right)$, ANP $\left(203.02 \mathrm{~cm} \mathrm{~cm}^{-3}\right)$ and MP $\left(143.69 \mathrm{~cm} \mathrm{~cm}^{-3}\right.$ ) (Figure 3). Based on this study, similar results were reported that the increases in root length density through nitrogen uptake efficiency strictly related to nitrogen uptake characteristics of the root system and the availability of nitrogen, carbohydrate and nitrate in the rhizosphere (Henry and Raper, 1991; Scholberg et al., 2002; Zotarelli et al., 
2008)Moreover, the root length density growth was increased during maize growth due to continuous deposition of organic matter, fertilization, cultivation (Marschner, 2011), demand of mineral nutrient (Peng et al., 2012) and closely related to soil moisture absorption (Kashiwagi et al., 2006). Consequently, the greater addition of mineral nutrients and high yields were related with greater total root length at maturity (Ning et al., 2015). In addition, the major reason for differences in root growth in each POME sludge treatments may be associated to the the nitrogen mineralization rate (Bilalis et al., 2010). This study had proven that adequate amount of nutrients present in the different POME sludge treatments might increase the maize growth performance and root length density (RLD). Peng et al., (2012) reported that about 50\% loss of maize root length occurred during root washing. The actual root length in the soil should be much higher than those shows in Figure 3.

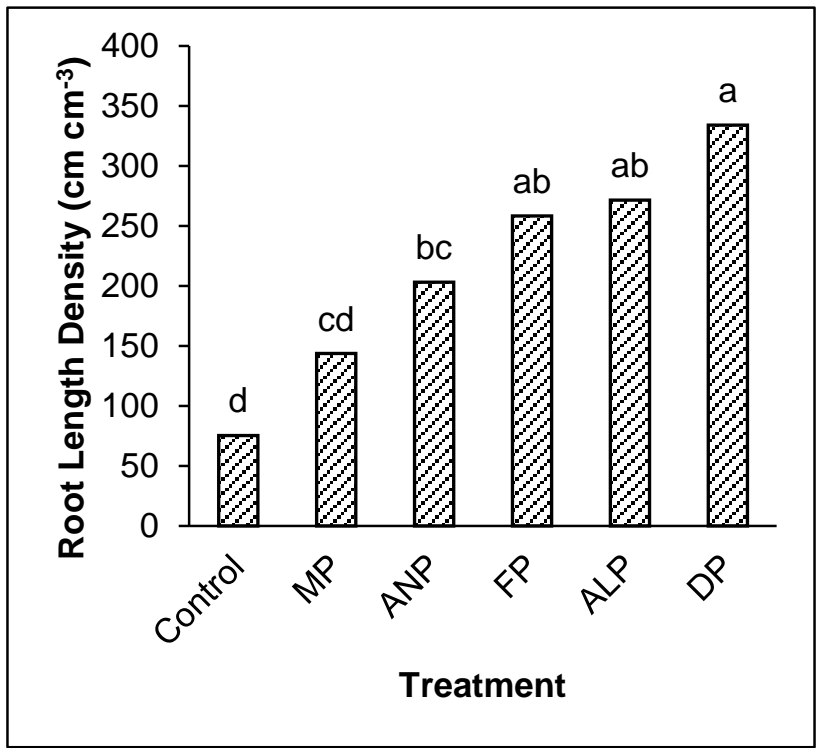

Figure 3: Effect of treatments on root length density (Means with the same letter are not significantly different at $p<0.05$ )

\section{Shear strength parameter}

Figure 4 shows the results of shear strength from the different POME sludge treatments. The analyzed data indicates that there was significant different of shear strength $(\mathrm{p}<0.05)$ compared to all the treatments. The shear strength in the DP treatment $\left(500.72 \mathrm{kN} \mathrm{m}^{-2}\right)$, ALP (464.14 $\left.\mathrm{kN} \mathrm{m}^{-2}\right), \mathrm{FP}\left(462.83 \mathrm{kN} \mathrm{m}^{-2}\right)$, ANP $\left(454.39 \mathrm{kN} \mathrm{m}^{-2}\right)$ and MP $\left(449.67 \mathrm{kN} \mathrm{m}^{-2}\right)$. The control treatment $\left(422.95 \mathrm{kN} \mathrm{m}^{-2}\right)$ showed the lowest result of shear strength. Shear strength results were correlated to the moisture content and organic matter factor. Hence, was highly affected by the clay material in the soil (Bláhová et al., 2013). The water content in the soil also correlated with organic matter in the soil profile. Organic matter increased the water holding capacity (WHC) at the optimum level (Bot and Benites, 2005). Organic matter also improved the quality of water infiltration and retention capacity of the soil and contributed to the availability of nutrients for plant uptake.

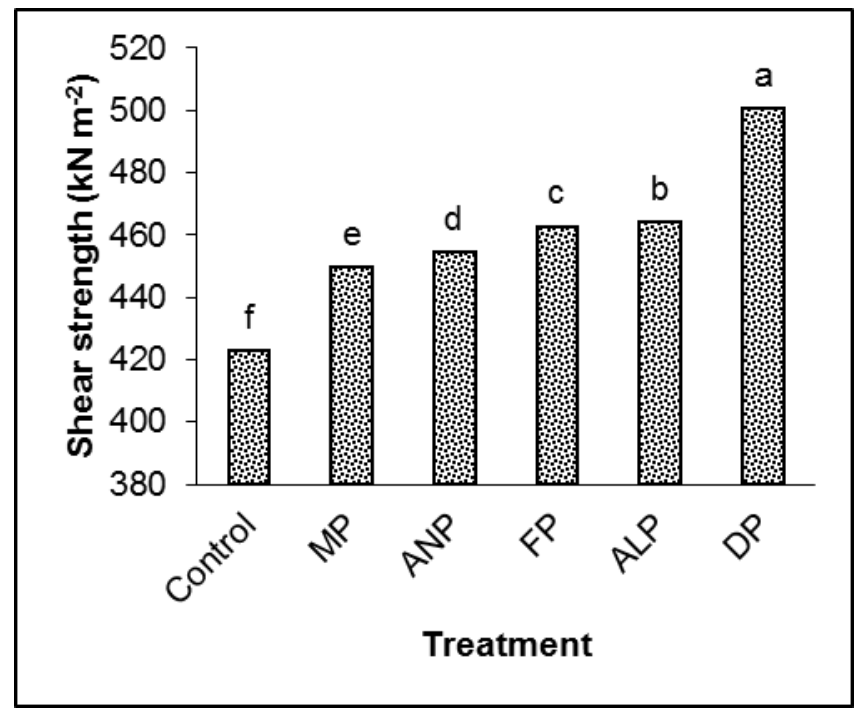

Figure 4: Effect of shear strength in the different POME sludge treatments (Means with the same letter are not significantly different at $\mathbf{p}<0.05$ )

\section{Roots shear strength}

Data in Figure 5 indicated the results of six different treatments on the effect of roots reinforcement towards the shear strength. The maize treated with DP treatment was significantly different on shear strength analysis and root length density (RLD) (Figure 3 and Figure 4). The high densities of plant roots in this treatment enhanced better anchorage and provided better aggregates stability to the Entisols. Generally, the graph showed that the shear strength was obtained after the application of normal stress at $100 \mathrm{kN} \mathrm{m}^{-2}, 200 \mathrm{kN} \mathrm{m}^{-2}$ and $300 \mathrm{kN} \mathrm{m}^{-2}$ in all samples. The peak strength or shear strength was plotted for different POME sludge that was used in the soil as treatment. Relatively, the DP treatment was low cohesion, c, while the angle of internal friction, $\phi$, increased and the shear stress at failure was obtained from the shear strength equation. The maximum shear strength in DP treatment was $500.72 \mathrm{kN} \mathrm{m}^{-}$ ${ }^{2}, \phi$ was $30^{\circ}$ and the root density was observed at $334.16 \mathrm{~g}$ $\mathrm{m}^{-3}$ (Table 1). The treatment with high root density in ALP with $271.7 \mathrm{~g} \mathrm{~m}^{-3}$ showed the decrease of cohesion value to 135 and $\phi$ value was slightly increased. The maize treated with DP treatment indicated high shear strength compared to all the treatments (Figure 5). The result had shown that 
Table 1: Soil and POME sludge treatment indicated root density and shear strength parameter of Entisols.

\begin{tabular}{|c|c|c|c|c|}
\hline Treatment & $\begin{array}{c}\text { Root density (cm } \\
\left.\mathbf{c m}^{-3}\right)\end{array}$ & Cohesion (c) & $\begin{array}{c}\text { Angle of Internal } \\
\text { Friction }(\phi)\end{array}$ & $\begin{array}{c}\text { Shear strength }\left(\mathrm{kN} \mathrm{m}^{-2}\right) \\
(\tau)\end{array}$ \\
\hline Control & 75.53 & 140 & $25^{\circ}$ & 422.95 \\
\hline MP & 143.69 & 135 & $26^{\mathrm{O}}$ & 449.67 \\
\hline ANP & 203.02 & 130 & $27^{\mathrm{O}}$ & 454.39 \\
\hline FP & 258.24 & 120 & $28^{\mathrm{O}}$ & 462.83 \\
\hline ALP & 271.7 & 100 & $29^{\mathrm{O}}$ & 464.14 \\
\hline DP & 334.16 & 80 & $30^{\circ}$ & 500.72 \\
\hline
\end{tabular}

the presence of high root density might increase the shear strength of Entisols. Ali and Osman (2008) reported that roots system and roots density increased the shear strength of the soil. The cohesion value in control treatment was slightly lower than the other treatments. While the cohesion value (c) was low, the $\phi$ value tends to increase.

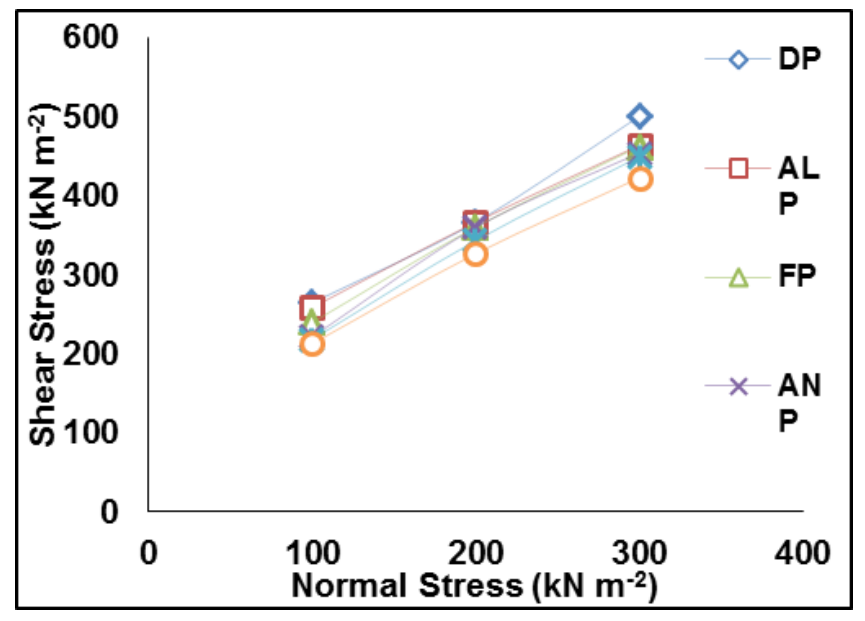

Figure 5: Relationship of shear stress and normal stress for POME sludge treatment (control, MP, ANP, FP, ALP and DP)

\section{The relationship of shear strength and moisture content}

The analyses of linear correlation showed that there was a positive correlation between shear strength $\left(\mathrm{kN} \mathrm{m}^{-2}\right)$ and moisture content (\%) from each of the treatments (Figure 6). The application of POME sludge was able to reduce the bulk density and improve fertily status of Entisols. In addition, increase of water content also correlated to the volume of pore distribution in the soil. The POME sludge treatment significantly increased water holding capacity of the soil. Bláhová et al., (2013) reported that shear strength of soils is highly affected by moisture conditions. Soil texture also contributes to the increase of water content especially if the soil contains high clay materials. In this experiment, Entisols contained $13 \%$ of clay. Increased clay contents in the soil can improve the plasticity (Bingjian, et al., 2013). Nevertheless, relationships derived from this study also indicated similar results that higher the shear strength, the greater the influence of moisture content on the values of the angle of internal friction and cohesion (Zydron and Dqbrowska, 2012).

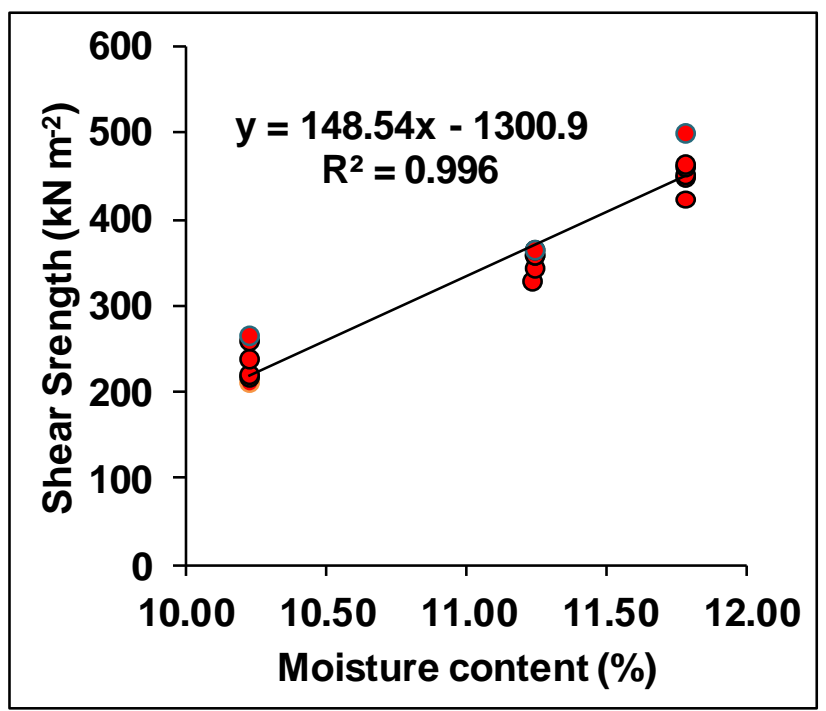

Figure 6: Correlation between shear strength $\left(\mathrm{kN} \mathrm{m}^{-2}\right)$ and moisture content $(\%)$

\section{The relationship of shear strength and root lenght density}

Figure 7 shows the significant effect or positive correlations between shear strength $\left(\mathrm{kN} \mathrm{m}^{-2}\right)$ and root length density $\left(\mathrm{cm} \mathrm{cm}^{-3}\right)$. The highly significant correlation was identified in all the treatments $\left(R^{2}=0.9615\right)$. Effects of the treatments with high organic matter; FP, ALP and DP sludge was able to improve the soil physical properties and 
increased soil water holding capacity which highly benefited for roots plant uptake (Isa et al., 2017). In addition, roots absorbed water and enabled the plant to maintain its turgidity. Furthermore, soils with high organic matter content and cation exchange capacity (CEC) cause mineral elements in soil to be transferred or absorbed by the roots, especially potassium (K) (Jones and Jacobsen, 2005).

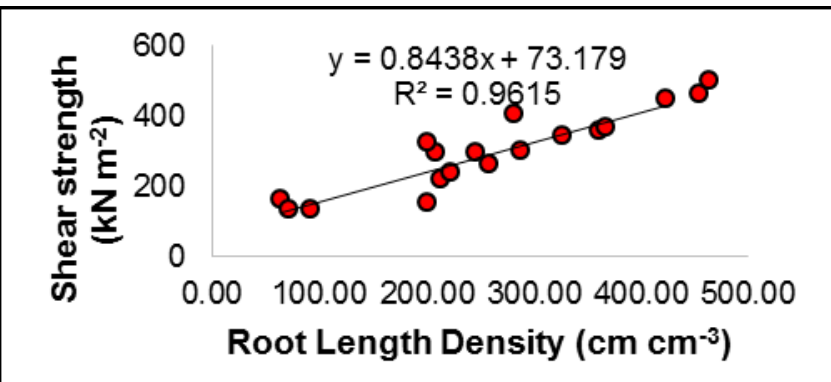

Figure 7: Correlation between shear strength $\left(\mathrm{kN} \mathrm{m}^{-2}\right)$ and root length density $\left(\mathrm{cm} \mathrm{cm}^{-3}\right)$.

\section{Conclusion}

The maize production treated with POME sludge from the dumping pond (DP) was the best soil amendment in this studies which was capable to increase the soil shear strength with low cohesion and high angle of internal friction contributed by the root densities and roots elongation. It was obviously shown that the appropriate and suitable organic amendment might increase roots reinforcement and shear strength of the Entisols. Furthermore, POME sludge amendment significantly affects the bulk density, soil compaction, increased porosity and organic matter content of the soil.

\section{Acknowledgements}

The authors would like to express gratitude to the Universiti Sultan Zainal Abidin (UniSZA), Universiti Putra Malaysia (UPM) and Universiti Teknologi MARA Pahang for the facilities assistance of this project.

\section{References}

Abernethy, B. and I.D. Rutherfurd. 2000. The effects of riparian tree roots on the mass stability of riverbanks. Earth Surface Processing Landforms 25: 921-937.

Ali, F.H. and N. Osman. 2008. Shear strength of a soil containing vegetation roots. Soils and Foundations 48 (4): 587-596.

Ball, J. 2001. Soil and water relationships. The Samuel Roberts Noble Foundation, Inc.

Bigdeli, M. and M. Seilsepour. 2008. Investigation of metals accumulation in some vegetables irrigated with waste water in Share Rey-Iran and toxicological implications. American-Eurasian Journal Agriculture \& Environmental Science 4(1): 86-92.

Bilalis, D., A. Karkanis, V. Triantafyllidis, A. Ladavos, D. Bizos, S. Patsiali, A. Efthimiadou and Y. Papatheohari. 2010. Effects of organic and inorganic fertilization on growth, yield and nicotine content of flue-cured and oriental tobacco (Nicotiana tabacum L.) seedlings grown in organic and conventional float system. Journal of Food, Agriculture \& Environment 8(2): 585-589.

Bingjian, Z., Q. Zhanhong, X. Hao, H. Chunmu and C. Helong. 2013. Effect of water content on the shear strength parameters of municipal solid waste. Electronic Journal of Geotechnical Engineering 18: 1181-1188.

Bláhová, K., L. Ševelová and P. Pilařová. 2013. Influence of water content on the shear strength parameters of clayey soil in relation to stability analysis of a hillside in Brno region. Acta Universitatis Agriculturae et Silviculturae Mendelianae Brunensis 61: 174.

Blake, G. R. and K.H. Hartge. 1986. Particle density. Methods of Soil Analysis: Part 1 Physical and Mineralogical Methods: 377-382.

Bot, A. and J. Benites. 2005. The importance of soil organic matter: Key to drought-resistant soil and sustained food production (No. 80). Food Agriculture Organization (FAO), United Nations.

Chaudhari, P.R., D.V. Ahire, V.D. Ahire, M. Chkravarty and S. Maity. 2013. Soil bulk density as related to soil texture, organic matter content and available total nutrients of Coimbatore soil. International Journal of Scientific and Research Publications $3(2): 1-8$.

Coulomb, C.A. 1776. Essai sur une application des regles de maximums et de mathematique et de physique. Academie Royale des Science, Paris 3: 38.

Embrandiri,A., R.P. Singh and M.H. Ibrahim. 2013. Biochemical, morphological, and yield responses of lady's finger plants to varying ratios of plam oil mill waste (decanter cake) application as a bio-fertilizer. International Journal of Recycling of Organic Waste in Agriculture 2: 1-7.

Hao, X. H., S.L. Liu, J.S. Wu, R.G. Hu, C.L. Tong and Y.Y. Su. 2008. Effect of long-term application of inorganic fertilizer and organic amendments on soil organic matter and microbial biomass in three subtropical paddy soils. Nutrient Cycling in Agroecosystems 81(1): 17-24.

Head, K.H. 1982. Manual of Soil Laboratory Testing. Volume 2: Permeability, shear Strength and 
Compressibility Tests. Pentech Press, Plymouth, London: 509-572.

Henry, L.T. and C.D. Raper. 1991. Soluble carbohydrate allocation to roots, photosynthetic rate of leaves, and nitrate assimilation as affected by nitrogen stress and irradiance. Botany Gazette 152: 23-33.

Isa, I., J. Shamshuddin and M.N. Khairuddin. 2017. Effects of mix vegetation and root shear strength grown on carbonaceous shale. Asian Journal Applied Science 11: $1-13$.

Jones, C. and J. Jacobsen. 2005. Plant nutrition and soil fertility. Nutrient Management Module 2: 11.

Kashiwagi, J., L. Krishnamurthy, J.H. Crouch and R. Serraj. 2006. Variability of root length density and its contributions to seed yield in chickpea (Cicer arietinum L.) under terminal drought stress. Field Crops Research 95(2): 171-181.

Kelepesi, S. and N.G. Tzortzakis. 2009. Olive mill wastes-a growing medium component for seedling and crop production of lettuce and chicory. International Journal of Vegetable Science 15(4): 325-339.

Khaleel, R., K. Reddy and M. Overcash. 1981. Changes in soil physical properties due to organic waste applications: a review. Journal of Environmental Quality, 10(2): 133-141.

Khairuddin, M. N., A.J. Zakaria, I.M. Isa, H. Jol, W.M.N.W.A. Rahman and M.K.S. Salleh. 2016. The Potential of treated palm oil mill effluent (Pome) sludge as an organic fertilizer. AGRIVITA. Journal of Agricultural Science 38(2): 142-154.

Kowalenko, C.G. 2001. Assessment of Leco CNS-2000 analyzer for simultaneously measuring total carbon, nitrogen, and sulphur in soil. Communications in Soil Science and Plant Analysis 32(13-14): 20652078.

Kumari, K. G.I.D., P. Moldrup, M. Paradelo, L. Elsgaard, H. Hauggaard-Nielsen and L.W. de Jonge. 2014. Effects of biochar on air and water permeability and colloid and phosphorus leaching in soils from a natural calcium carbonate gradient. Journal of Environmental Quality 43(2): 647-657.

Marçal Silva, M. D., A.S. Ferreira Araújo, L.A. P.L. Nunes, W.J. de Melo and R.P. Singh. 2013. Heavy metals in cowpea (Vigna unguiculata L.) after tannery sludge compost amendment. Chilean Journal of Agricultural Research 73(3): 282-287.

Marschner, P. 2011. Mineral Nutrition of Higher Plants, third Ed. Academic Press, London.

Mohamad Nordin, A., O. Normaniza and H.A. Faisal. 2011. Soil-root shear strength properties of some slope plants. Sains Malaysiana 40(10): 1065-1073.

Mohr, O. 1900. Welche umstande bedingen die elastizitatsgrenze und den bruch eines materials.
Zeitschrift des Vereins Deutscher Ingenieur 44: 1524-1530.

Morgan, R.P.C. 1996. Soil Erosion and Conservation. Longman group UK limited: 2-10.

Ning, P., S. Li, P.J. White and C. Li. 2015. Maize varieties released in different eras have similar root length density distributions in the soil, which are negatively correlated with local concentrations of soil mineral nitrogen. PloS one 10(3): 1-16.

Normaniza, O. and S.S. Barakbah, 2006. Parameters to predict slope stability-Soil water and root profiles. Ecological Engineering 28: 90-95.

Pagliai, M. and M. De Nobili. 1993. Relationships between soil porosity, root development and soil enzyme activity in cultivated soils. Geoderma $56: 243-256$.

Pascual, J. A., C. Garcia, T. Hernandez and M. Ayuso. 1997. Changes in the microbial activity of an arid soil amended with urban organic wastes. Biology and Fertility of Soils 24(4): 429-434.

Peng, Y., P. Yu, Y. Zhang, G. Sun, P. Ning, X. Li and C. Li. 2012. Temporal and spatial dynamics in root length density of field-grown maize and NPK in the soil profile. Field Crops Research 131: 9-16.

SAS Intstitute Inc. 2007. SAS/STAT software, version 9, Cary, NC, USASAS Institute, Inc.

Scholberg, J.M.S., L.R. Parsons, T.A. Wheaton, B.L. McNeal and K.T. Morgan. 2002. Soil temperature, nitrogen concentration, and residence time affect nitrogen uptake efficiency in citrus. Journal Environmental Quality 31:759-768.

Shang, L., S. Cai, L. Ma, Y. Wang, A. Abduweli, M. Wang, X. Wang, Q. Liang and J. Hua. 2016. Seedling root QTLs analysis on dynamic development and upon nitrogen deficiency stress in Upland cotton. Euphytica, 207(3): 645-663.

Silva, M.D., A.S.F. Araújo, L.A. Pinheiro L. Nunes, W.J. de Melo, and R.P. Singh. 2013. Heavy metals in cowpea (Vigna unguiculata L.) after tannery sludge compost amendment. Chil.J. of Agr. Res. 73(3): 282287.

Silva, J.D., T.T, Leal, A.S. Araújo, R.M. Araujo, R.L. Gomes, W.J. Melo and R.P. Singh. 2010. Effect of different tannery sludge compost amendment rates on growth, biomass accumulation and yield responses of Capsicum plants. Waste Management 30(10): 1976-1980.

Singh, R.P. and M. Agrawal. 2010. Effect of different sewage sludge applications on growth and yield of Vigna radiata L. field crop: Metal uptake by plant. Ecol. Eng. 36(7): 969.

Tan, K.H. 2003. Soil Sampling, Preparation and Analysis. New York, NY, USA: Taylor \& Francis. 
Terzaghi, K. and R.B. Peck. 1967. Soil Mechanics in Engineering Practice. Wiley, New York: 1-300.

Teh, C.B.S. and J. Talib. 2006. Soil physics analyses: volume 1. Universiti Putra Malaysia Press.

USDA. 2008. Soil bulk density/moisture/aeration. United State Department of Agriculture Natural Resources Conservation Services (NRCS), USA. 1-11.

Zydroń, T. and J. Dąbrowska. 2012. The influence of moisture content on shear strength of cohesive soils from the landslide area around Gorlice. $A G H$ Journal of Mining and Geoengineering 36: 309-317.
Zotarelli, L., J.M. Scholberg, M.D. Dukes and R. MuñozCarpena. 2008. Fertilizer residence time affects nitrogen uptake efficiency and growth of sweet corn. Journal of Environmental Quality 37(3): 12711278. 